\title{
Social Capital Determinants of Preferential Resource Allocation in Regional Clusters**
}

Regional clusters are known to facilitate firms in achieving higher levels of competitive advantage. This observation suggests that cluster firms manage to obtain better competitive resources than firms outside the cluster. The strong social ties in regional clusters are considered to be a crucial factor in the resource exchange between cluster firms. In this paper, we integrate this social perspective from the cluster literature with a recent stream in the resource-based view (RBV) literature. This stream seeks to explain the phenomenon of preferential resource allocation. That is, how can firms obtain better resources from a resource environment that is shared with competitors? Although preferential resource allocation has revealed to be a relevant concept, little is known about its actual antecedents. We introduce a conceptual framework that builds on the social interactions among cluster firms to explain the concept of preferential resource allocation. More specifically, we develop propositions on the antecedents of preferential resource allocation by building on the structural, relational, and cognitive dimensions of social capital theory, and a firm's embeddedness in a regional cluster. In so doing, this paper provides insights that may contribute to a better understanding of the competitive advantage of cluster firms, and it opens onto current streams in the RBV literature.

Key words: regional clusters, preferential resource allocation, resource competition, inter-firm resource exchange

(JEL: L10)

* University of Twente, School of Management and Governance, Department of Business Administration, P. O. Box 217, 7500 AE Enschede, The Netherlands.

Corresponding author. E-mail address: n.j.pulles@utwente.nl.

** Article received: April 11, 2012

Revised version accepted after double blind review: March 19, 2013. 


\section{Introduction}

Firms benefit from being located in a cluster. For example, firms in clusters tend to be more innovative than isolated firms (Baptista \& Swann, 1998; Molina-Morales \& Martinez-Fernandez, 2003). In fact, research in economic geography has highlighted that innovations have a tendency to appear in a concentrated way in selected centers (Breschi \& Lissoni, 2001; Feldman, 1999). As a result, firms in regional clusters appear to have an advantage and have shown to be more profitable than their isolated competitors in the same industry (Fabiani \& Pellegrini, 1998).

The concept of regional clusters refers to a group of interconnected actors within a particular field and their characteristic of tight geographical boundedness (Porter, 1998; Tallman, Jenkins, Henry, \& Pinch, 2004). However, proximity alone between firms is not a sufficient explanation for the competitive advantage of regional cluster firms firms (Kukalis, 2010; Mitchell, Burgess, \& Waterhouse, 2010; Zaheer \& George, 2004). Instead, the social connectivity and interaction between the actors seem to be a more adequate explanation (Dijk \& Sverrisson, 2003; Doloreux \& Parto, 2005; Steinle, Schiele, \& Mietzner, 2007), as these factors are argued to be facilitated by the proximity and size of the cluster (Kajikawa, Takeda, Sakata, \& Matsushima, 2010). Within the stream of literature addressing the social interaction within cluster firms, it has been argued that the strong ties among cluster firms enable resource exchange on different levels in the cluster (e.g., Brown et al., 2007; Brown et al., 2010; Gulati, Lavie, \& Madhavan, 2011). For example, it has been shown that members of a cluster have a higher intensity of resource exchange compared to firms that do not belong to a cluster (Molina-Morales \& Martinez-Fernandez, 2003). Tallman, Jenkinks, Henry, and Pinch (2004) observed that economic geographers view resource exchange as critical in defining the competitive advantage of regional clusters.

However, resource exchange alone might not be sufficient to explain the competitive advantage of firms in clusters. From a resource-based view (RBV), competitive advantage is a relative notion that implies that firms must obtain better resources than their competitors to be competitive. Firms with a comparative advantage in resource access will more easily attain a position of competitive advantage (Hunt \& Davis, 2008). Current streams of RBV literature addresses the question of how firms can attain better resources than their competitors. The main idea in this stream is that firms should aim for preferential resource allocation from their partners (Steinle \& Schiele, 2008). Firms can only share their best resources, such as ideas, new technologies, scarce materials, or most experienced personnel, with a limited number of partners. Preferential resource allocation refers to a situation in which a firm obtains better resources from its partners than other firms that have similar demands from these partners. Although conceptually and empirically the concept of preferential resource allocation has revealed to be relevant (Baxter, 2012; Ellis, Henke Jr., \& Kull, 2012; Schiele, Veldman, \& Hüttinger, 2011), little is known about the antecedents of preferential resource allocation. In fact, the seminar case study of Steinle and Schiele (2008), which emphasized the relevance of being a preferred customer of key suppliers, was conducted in a cluster setting and discussed firms trying (and failing) to access partners located in remote clusters. Still, this empirical observation of privileged resource 
allocation among clustered firms as opposed to serving their remote customers did not find any conclusive theoretical explanation. Our paper argues that social capital theory may provide such an explanation, thereby offering a perspective for further research on this phenomenon.

Therefore, in this paper, we introduce a conceptual framework that combines perspectives on social capital and cluster embeddedness to explain the phenomenon of preferential resource allocation. We consider the social interactions observed among cluster firms to explore the antecedents of preferential resource allocation among firms. Therefore, this paper opens onto the literature on preferential resource allocation by developing testable propositions regarding the antecedents of preferential resource allocation, thereby bridging the cluster and RBV literatures.

\section{Preferential resource allocation, cluster embeddedness, and social capital}

In the following sections, we discuss the concept of preferential resource allocation and explain the concepts of regional clusters, cluster embeddedness, and the different dimensions of social capital. First, in section 2.1 we use the RBV to argue how preferential resource allocation links to the competitive advantage of firms. Then, in section 2.2 we discuss the concept of cluster embeddedness. In section 2.3 we describe how cluster embeddedness facilitates social interaction between firms in a regional cluster, and link the social interaction to firms to preferential resource allocation in regional clusters. In section 2.4 we introduce the three dimensions of social capital theory we use to build proposition in Chapter 3 on how regional clusters are positively associated with the concept of preferential resource allocation.

\subsection{Preferential resource allocation as source of competitive advantage}

From the RBV, the competitive advantage of a firm "can be understood as a function of the combined value and rarity of all firm resources and resource interactions" (Lavie, 2006, p. 643). Resources are defined as the tangible or intangible financial, human, intellectual, organizational, and physical entities available to the firm that enable the firm to increase its competitive advantage (Hunt \& Davis, 2008; Newbert, 2008). Thus, when firms are in a resource exchange relationship, both of the firms allocate tangible or intangible entities to the relationship from which the partner firm derives advantage. Resources are said to endow a sustainable competitive advantage on a firm to the extent that they are valuable, rare, and difficult to imitate or substitute (Barney, 1991; Capron \& Chatain, 2008). Collaborations with external partners are important mechanisms for firms as the firms seek to enhance their competitive advantage by developing and acquiring resources from external partners (Freiling, 2004).

The importance of retaining resources from the firm's external environment receives much support in the management literature. For example, Dyer and Singh (1998) proposed a "relational view of the firm". Others discuss "systemic competencies" (Mildenberger, 2001), "inter-firm resources" (Duschek, 2004), "network resources" (Gulati, 1999), cluster-embedded core competencies (Steinle, Eickhoff, \& Schiele, 1998), "firm addressable" external resources (Sanchez \& Heene, 1997) or an alliance-view, which asks firms to draw on other firms' competencies and integrate 
them (Das \& Teng, 2000; Ireland, Hitt, \& Vaidyanath, 2002). It is interesting to note that there is also a - largely unconnected - stream of research discussing regional competencies, which, to a certain extent, are collective in character but can only be accessed through firms located in that particular region (Best, 1999; Enright, 1998; Foss, 1999; Lauterbach, 2005; Maskell \& Malmberg, 1999; Mathews, 2002). The common core of all these concepts is that firms require not only internal resources but also resources located outside their boundaries and that they can achieve competitive advantages if they can gain privileged access to these resources. This approach was not considered an option in the original version of the RBV of the firm.

In practice, the number of inter-firm collaborations has increased substantially over recent decades, and collaborations have become a central strategic component for many firms (Lavie, 2007). However, as an increasing number of firms seek resources in external environments, obtaining an advantage over competitors sourcing from the same environment is becoming more difficult. From the RBV, external resources that provide firms a unique competitive position are, by definition, scarce. Therefore, when more competitors are acting in similar resource environments, it becomes more difficult for firms to attain a competitive advantage. An example of such a resource environment is a supply base, in which buying firms aim to achieve a preferred customer status to obtain better resources than competing firms that source from the same supply base (Steinle \& Schiele, 2008). Such a preferred status makes suppliers commit to the relationship and invest resources preferentially to the relationship (Baxter, 2012). Gulati and colleagues unveil the key challenge. Actors have limits to the resources they can devote and "may only have the time and resources to form and satisfy the expectations of a limited number of alliances. By making choices to ally with some partners, others are ipso facto excluded" (Gulati, Nohria, \& Zaheer, 2000, p. 210).

Accordingly, a study by Lavie (2007) indicates how an increase in the level of competition in resource environments is negatively associated with a firm' s market performance. As a consequence, competitors acting in similar resource environments fiercely compete for resources and deploy strategies to degrade the resource position of their rivals (Capron \& Chatain, 2008). In these competitive resource environments, firms that are able to attain a better position than their competitors can be expected to attain competitive advantages. Recent literature on buyer-supplier relationships explains the effects of preferential resource allocation. For example, preferential resource allocation might include the first offering of a new technology or the delegation of the most experienced engineering team to a collaborative NPD project (Hüttinger, Schiele \&Veldman 2012). Similarly, Ellis, Henke, and Kull (2012) found that preferential treatment is positively related to the willingness of a supplier to provide the buying firm with access to its new technologies. Therefore, buying firms are explained to apply strategic approaches to attain such preferential treatment (Nollet, Rebolleda \& Popel, 2012).

Without attaining better resources than its competitors, a firm cannot be expected to gain a competitive advantage through inter-organizational relations over firms competing within the same resource environment. Attaining preferential resource allocation from an external resource environment shared with primary compet- 
itors is, therefore, essential for firms to gain an competitive advantage. Regional clusters may explain the resource allocation mechanisms.

\subsection{Cluster embeddedness and social interaction between firms}

The cluster concept is often associated with Michael E. Porter (1990), whose "diamond of competitive advantage" constitutes one of the most influential concepts on clusters. Porter' s approach, despite mentioning "social glue", mainly focuses on the structure of an agglomeration. The diamond implies that the presence of several producers, their suppliers, trend anticipating customers and supportive institutions already make up for a cluster. However, in contrast to the implications of Porter' s diamond model, the mere presence of a set of actors in a region has been found not to be sufficient to achieve competitive results (Dijk \& Sverrisson, 2003; Kukalis, 2010; Steinle et al., 2007). To explore the diverse aspects of innovation processes in regional economic milieus (Aydalot, 1986; Crevoisier, 2004), a prominent ' milieu' approach focused on the interaction in locally embedded social systems (Zaheer \& George, 2004). From the interaction perspective, a cluster is characterized as a learning environment wherein an intensive exchange among companies and catalyzing institutions forms the basis for collaboration. Clusters are interpreted as complex social systems rooted in space. Through the intensive, often informal, information exchange, trust can develop, thereby reducing problems of opportunism and fostering collaboration.

Without social interaction between cluster firms, the proximity advantages of regional clusters would, in general, only confine low costs of transactions and lower switching costs for employees (Mitchell, et al., 2010; Steinle \& Schiele, 2002). However, when the proximity advantages allow constructive interaction in which value is created, cluster firms may expect to grasp substantially more benefits from their interfirm collaborations than firms outside the cluster. Firms strongly embedded into regional clusters can, therefore, be expected to benefit more from their interorganizational relationships. In this paper, we use the term cluster embeddedness to describe this phenomenon. We adopt a perspective on inter-firm interaction by Heide and Miner (1992) and cluster embeddedness by Wood, Watts, and Wardle (2004) and thus put forward the following definition:

Cluster embeddedness is the extent to which firms are integrated into the regional cluster and the interactions with other cluster firms in which concrete opportunities for resource exchange and co-creation of new resources arise.

We consider the main advantages of cluster embeddedness, therefore, not to be the ease in which the partners interact (as is the main advantage from the transactional perspective) but as the deepening of the resource base that this interaction enables (Maskell, 2001). Thus, the importance of cluster embeddedness lies in the local access and co-creation of resources as expertise and technologies and may, therefore, be an important factor in explaining the competitive success of numerous cluster firms (Keeble, Lawson, Smith, Moore, \& Wilkinson, 1998). A proposal on how to measure cluster embeddedness of firms has been proposed by Steinle et al. (2007).

\subsection{Preferential resource allocation in regional clusters}

From the RBV, the competitive advantage of regional clusters is explained by the resources that cluster firms possess or can access. The social interaction between firms, 
as observed in regional clusters, serves as an important foundation for this competitive advantage. Therefore, the social interactions between cluster firms enable them to obtain better resources than can firms located outside of the cluster. We argue that a key factor in the competitive advantage of clusters is that firms within a cluster allocate to one another preferential resources relative to firms that do not belong to a regional cluster. In other words, cluster firms are more likely to allocate superior resources to other cluster firms and, consequently, allocate inferior resources to firms outside the cluster. Therefore, firms in clusters are better able to attain prime resources from their external environments than are firms outside the cluster; for instance, suppliers may award their customers in the same cluster preferred customer status while treating external customers in a less privileged manner (Steinle \& Schiele, 2008). If matched appropriately to environmental opportunities, distinctive or superior resources -relative to those of rivals- form the basis for competitive advantage (Peteraf, 1993). Therefore, we consider preferential resource allocation to be a key factor in the competitive advantage firms in regional clusters have compared to firms that do not belong to a cluster.

Figure 1 illustrates the main idea of differentiation of partner treatment.

Figure 1: Preferential resource allocation in regional clusters

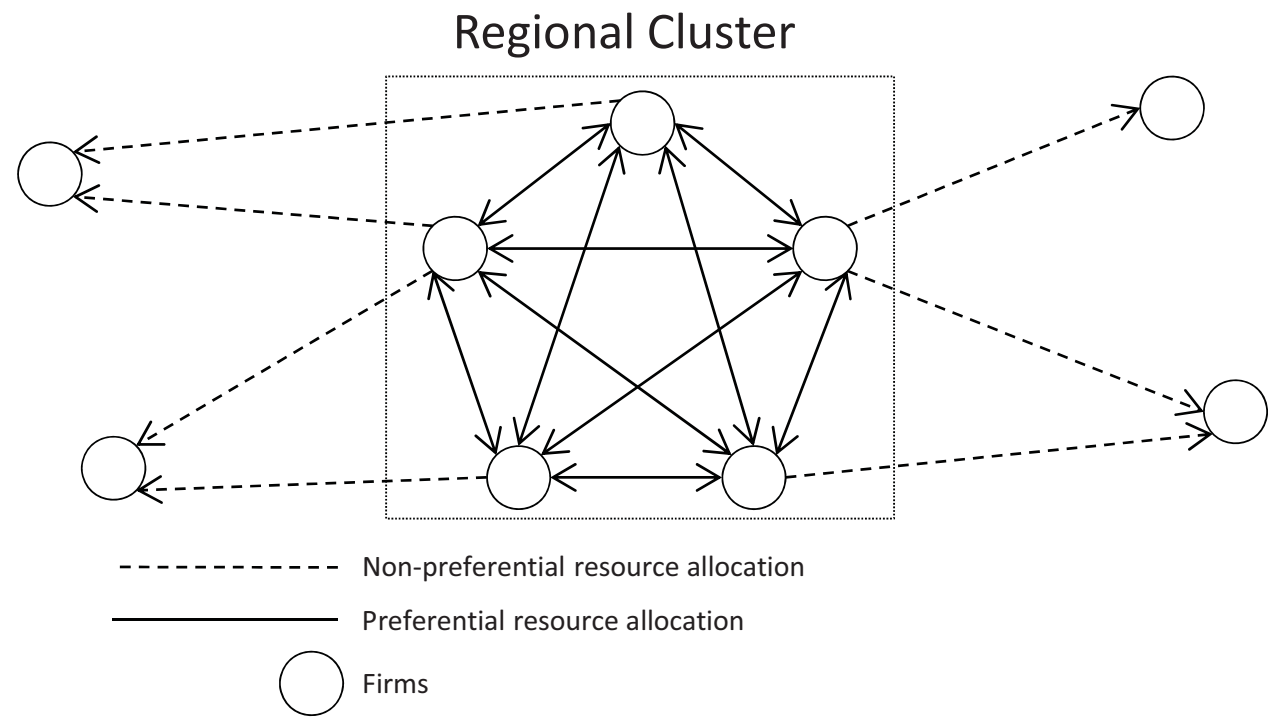

To locate the antecedents of preferential resource allocation, the following sections propose a social capital theory based framework that builds on the effects of social interactions between firms and the effects of a firm's cluster embeddedness. Based on the models of Nahapiet and Ghoshal (1998) and Wasko and Faraj (2005), we develop a set of propositions to examine how three dimensions of social capital of firms relate to preferential resource allocation. Before introducing the propositions, we briefly discuss the relevant dimensions of social capital in section 2.4. 


\subsection{Social capital perspectives on preferential resource allocation}

An important benefit of firms in regional clusters pertains to social proximity. Effectively communicating and sharing resources requires a high degree of mutual understanding, trust, and shared values (Maskell, 2001). Regional clusters facilitate this type of environment and create a club-like milieu (Steinle \& Schiele, 2002) in which firms can exchange resources through strong ties developed through close interactions. Social capital therefore seems to be essential for the process of managing resources in clusters (Gretzinger \& Royer, 2011). Social capital theories capture the different facets of the relational setting in which interactions between firms to co-create and exchange resources occur (Nahapiet \& Ghoshal, 1998). Social capital can be understood as the social ties between actors, whether individuals or corporate actors, that enable these actors to obtain certain benefits from these ties (Coleman, 1988; Portes, 1998). Therefore, social capital accounts for the contextual factors in which resource exchange occurs (Kankanhalli, Tan, \& Wei, 2005). Because social capital is argued to be "both the glue and a lubricant" (Rutten, Westlund, \& Boekema, 2010, p. 866) of the social relations in regional clusters, social capital theories are often used in cluster literature (Staber, 2007).

To develop our propositions, we adopt the dimensions of social capital theory as described by Nahapiet and Ghoshal (1998). These authors suggest that the co-creation and exchange of resources between firms is facilitated when (1) there are structural links or social ties between firms (structural capital), (2) the firms have a strong relationship built on trust (relational capital), and (3) the firms have a shared vision and shared interpretations of the relationship (cognitive capital) (Nahapiet \& Ghoshal, 1998; Tsai \& Ghoshal, 1998; Wasko \& Faraj, 2005). To build our conceptual framework, we utilize the structural, relational, and cognitive dimensions of social capital to examine the relational setting between firms that engage in resource exchange.

\section{Effects of social capital on preferential resource allocation, moderated by a firm' s cluster embeddedness}

In the following section, we introduce a conceptual framework that explains how the three dimensions of social capital are positively associated with the concept of preferential resource allocation between firms. We further argue that cluster embeddedness strengthens this effect. Social capital may also develop between firms outside a regional cluster, and, similarly, firms might be motivated to exchange resources with firms outside the cluster. Still, firms embedded within regional clusters can be expected to better utilize their social capital because of their proximity advantages and close interactions. Thus, we include propositions of a positive moderating effect between cluster embeddedness and the different dimensions of social capital.

Figure 2 summarizes the proposed framework. 
Figure 2: Conceptual framework

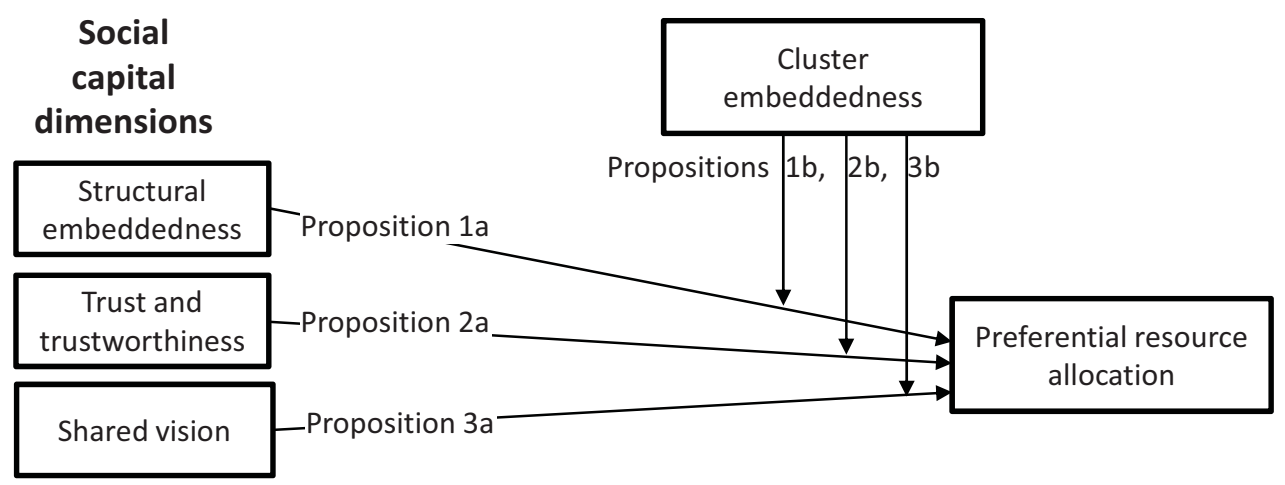

\subsection{Structural dimension}

The structural dimension of social capital refers to the density and strength of an actor' s social ties with its resource environment. These ties are connections that a firm shares with external partners and can be interpreted as channels for resource flow (Tsai \& Ghoshal, 1998). Nahapiet and Goshal (1998, p. 244) define structural embeddedness as the impersonal configuration of linkages between people or units. Therefore, structural embeddedness refers to the structure of ties, or connections, between firms that enables firms to interact with one another. Actors who are better embedded in their resource environment should have a competitive advantage over poorly embedded competitors (Rowley, Behrens, \& Krackhardt, 2000). This advantage is explained by the possibility of structurally embedded firms to utilize their social ties to attain resources from external partners. Actors who possess these social ties could, therefore, expect better resource accessibility than (competing) actors who do not possess such social ties.

At the business-unit level of multinational firms, Andersson, Forsgren, and Holm (2002), find that embeddedness in technical environments leads to better market performance. Through ties in this environment, business units are able to reap the benefits of knowledge and capabilities transferred from other units within the environment. The structural embeddedness of firms in their resource environment can be regarded as a distribution network for resources through which firms can attain resources from their external environment. Therefore, we propose the following:

Proposition 1a: Through higher levels of structural embeddedness in an external resource environment, firms attain higher levels of preferential resource allocation and, therefore, achieve higher levels of competitive advantage.

The literature makes a similar link between the interactions of firms and the strength of the ties between firms (e.g., McEvily \& Zaheer, 1999). The difference between structural embeddedness and cluster embeddedness is that while structural embeddedness refers to the configuration (i.e. structure) of a firm's ties (Moran, 2005) cluster embeddedness establishes how many ties a firm has with firms inside a regional 
cluster -and therefore refers to the proximity and the industry of the other actors- and the extent to which these ties are interacted through. Therefore, a firm can have either (1) a low structural embeddedness, (2a) many ties to other firms that are not geographically concentrated, or (2b) many ties with firms concentrated in a particular cluster. Cluster embeddedness and structural embeddedness are therefore not the same. Firms can have a high structural embeddedness (being linked to actors outside its cluster), but nevertheless have a low cluster embeddedness (i.e. few inter-cluster connections).

The social interaction in clusters is expected to increase the effectiveness of the ties between firms. A more frequent interaction through structural ties can increase the perceived value of a relationship (Palmatier, Gopalakrishna, \& Houston, 2006), and firms may become more willing to allocate resources to firms with whom they frequently interact. On an inter-personal level, for example, Brown and Reingen (1987) explain that ties with greater frequency of social contact are more likely to be activated for better information flow. The reduced physical distance, for example, is a catalyst of exchange, decreasing the costs of exchange and increasing the likelihood of a personal meeting. Furthermore, regional collaboration in such settings as associations, educational institutions, and infrastructure endeavors constitutes another opportunity for members of firms to meet. Therefore, if a firm has strong ties with its external environment (and thus has high levels of structural embeddedness), these ties are expected to be used more effectively to the extent that this firm is embedded within a regional cluster.

Proposition 1b: The positive effects of structural embeddedness on preferential resource allocation tend to increase as the cluster embeddedness of a firm increases.

\subsection{Relational dimension}

The relational dimension of social capital refers to the relational trust and trustworthiness rooted in relationships (Tsai \& Ghoshal, 1998). The main function of the relational dimension of social capital is to facilitate resource exchanges for actors within the resource environment (Wasko \& Faraj, 2005). Many social capital researchers suggest that trust is a main aspect of the relational dimension. When two actors trust one another, they are more willing to share resources without the fear of opportunistic behavior by the other party. Therefore, differences in levels of trustworthiness may relate to different levels of resource allocation from partner firms (Tsai \& Ghoshal, 1998). Trust relates to benevolence in resource allocation, as it creates the expectation that trusted actors will have a positive incentive to comply with the trustee' $\mathrm{s}$ wishes (Ridings, Gefen, \& Arinze, 2002).

Anderson, Lodish, and Weitz (1987) provide an example of the influence of relational capital on resource allocation behavior in channel management activities. In channel relationships, suppliers aim to induce, for example, retailers and wholesalers to devote more resources (e.g., shelf space or promotional actions) to selling their products. Accordingly, trusting channel relationships are shown to induce upstream partners to allocate more resources to selling the suppliers' products. Therefore, we propose the following: 
Proposition 2a: Through higher levels of relational trust and mutual trustworthiness as perceived by the external resource environment, firms attain higher levels of preferential resource allocation and, therefore, achieve higher levels of competitive advantage.

It is often argued that, for example, a key factor in the success of Italian industrial districts is the high degree of trust among cluster firms (e.g., Humphrey \& Schmitz, 1998). The frequent interactions and familiarity among firms in a regional cluster are often found to facilitate a climate of trust and mutual understanding (Dahl \& Pedersen, 2004). Therefore, higher levels of interaction can be expected to relate to higher levels of trust. When interactions between firms increase, firms may better utilize their trusted ties through repeated exchanges (Oba \& Semerciöz, 2005). In buyerseller relationships, for example, this interaction perspective has been found to support the potential value of inter-organizational cooperation (Heide \& Miner, 1992).

Clusters can be understood as clubs whose membership no actor wants to jeopardize by displaying opportunistic behavior (Steinle \& Schiele, 2002). With this fact in mind, cluster firms can more easily trust each other. Therefore, in addition to the proposed direct effect of trust and trustworthiness, we propose that the embeddedness of a firm in a regional cluster has a moderating effect on the relational dimension of social capital.

Proposition 2b: The positive effects of relational trust and mutual trustworthiness on preferential resource allocation tend to increase as the cluster embeddedness of a firm increases.

\subsection{Cognitive dimension}

The cognitive dimension of social capital refers to, as Nahapiet and Goshal stated, "shared representations, interpretations, and systems of meaning among parties" (Nahapiet \& Ghoshal, 1998, p. 244). When a firm and its partners have similar perceptions about how to interact, a mutual understanding is likely to occur. This shared vision and understanding with respect to goals and aspirations can be viewed as a mechanism for firms to more freely exchange resources (Inkpen \& Tsang, 2005; Tsai \& Ghoshal, 1998). An example can be found in work of Hult, Ketchen Jr., and Slater (2004), who argue that a shared vision links to resource distribution and the positive outcomes related to this distribution. They find a positive relationship between a shared vision and performance operationalization, such as cycle time reduction.

Through the cognitive dimension of social capital, other actors in the resource environment recognize the goals and interests they share, thus helping them to see the potential value of a resource exchange (Tsai \& Ghoshal, 1998). Cognitive capital between a firm and other actors can create a certain resource commitment within the environment towards the firm and therefore lead to higher performance levels (Krause, Handfield, \& Tyler, 2007). Accordingly, we propose the following:

Proposition 3a: Through shared visions and higher levels of mutual understanding with an external resource environment, firms attain higher levels of preferential resource allocation and, therefore, achieve higher levels of competitive advantage. 
Shared visions and mutual understandings in inter-firm relationships enable partners to more easily exchange works (Inkpen \& Tsang, 2005). Partners who share a vision see higher potential value in resource exchange and will, therefore, be more inclined to intensify their relationship of resource exchange (Tsai \& Ghoshal, 1998). The interaction frequency and intensity between firms have been found to be important mechanisms for establishing higher levels of mutual understanding (Leuthesser, 1997). Shared vision and mutual understandings about key features, are argued to strengthen the social interactions and, thereby, resource flows between actors in regional clusters (Romanelli \& Khessina, 2005).

Because of the common cultural and social background, actors in regional clusters often share the same values and norms (Dijk \& Sverrisson, 2003). It is these shared visions in a cluster that are described as being "extremely important" for the competitiveness of regional clusters (Hallencreutz \& Lundequist, 2003). Some authors see the common "leitbild", as shared frame of reference in a cluster, as core to the idea of a milieu (Fromhold-Eisebith, 1995). It is worth noting that, in a regional agglomeration with an innovative milieu, actors continuously undergo a process of common socialization, in the course of which they become increasingly similar and thereby develop shared cognitive capital (Franz, 1999; Maillat, 1990).

Proposition 3b: The positive effects of shared visions and higher levels of mutual understanding of preferential resource allocation tend to increase as the cluster embeddedness of a firm increases.

In sum, we argue that firms in a cluster profit from more structural capital due to the existence of more partners and easier connections to those partners than do dispersed firms. The interaction within a cluster is further fostered by the availability of cognitive capital, which is encouraged by a common ideal and similar socialization within a cluster. Finally, structural capital and cognitive capital are complemented by relational capital, which is developed more successfully in the club-like atmosphere of an innovative cluster. Departing from the assumption that the availability of social capital is an antecedent to preferential resource allocation and further assuming that firms in a cluster enjoy more abundant social capital, it can be concluded that firms embedded in a cluster are also likely to benefit from mutual preferential resource allocation.

\section{Conclusions and implications}

In this paper, we have integrated concepts from the cluster literature with those of a recent stream in the $\mathrm{RBV}$ literature and suggest that preferential resource allocation among firms is a critical factor in the competitive advantage of firms. We have introduced a conceptual framework in which the different dimensions of social capital are antecedents for preferential resource allocation. In addition, we included propositions that the extent to which firms are embedded in regional clusters strengthens the effect of social capital dimensions on preferential resource allocation. This framework offers a useful explanation for both the cluster literature and for the stream of RBV literature exploring the preferential resource allocation phenomenon, as this study provides several new insights. 
This paper contributes to literature on regional clusters by linking a recent stream in RBV literature to the cluster literature and propose that preferential resource allocation between cluster firms is an important factor in the competitive advantage firms in regional clusters have compared to firms that do not belong to a cluster. The RBV literature has widely accepted the importance of interorganizational resource creation and exchange (e.g., Das \& Teng, 2000; Dyer \& Singh, 1998). At the same time cluster literature has come to see resource exchange of cluster firms as critical to define the competitive performance of regional clusters (Brown, et al., 2007; Brown, et al., 2010; Festing, Royer, \& Steffen, 2010; Tallman, et al., 2004). We state that, firms in regional clusters allocate each other preferential resources and, as a consequence, allocate inferior resource to firms outside the cluster. Because of this resource advantage, cluster firms have a competitive advantage over firms in similar resource environments, but outside the cluster.

Next to this, although the concept of preferential resource allocation has shown its relevance in RBV literature, still little is known about the actual antecedents. Because of the often observed social interactions between cluster firms, we apply a social capital perspective to explore the antecedents of preferential resource allocation between firms. By taking this perspective, we addresses the hints several scholars provided towards resource competition in external environments. For instance, Takeishi (2001, p. 403) questions: "How could a company outperform competitors who also have cooperative relations with their partners?" The social capital perspective on preferential resource allocation provides new insights to an upcoming stream in literature that emphasizes on gaining better resources from supply bases. Supply bases are examples of resource environments in which firms compete for supplier's best resources (Dyer \& Hatch, 2006; Takeishi, 2002). Topics like customer attractiveness (Mortensen, Freytag, \& Arlbjørn, 2008; Ellegaard, 2012; Hald, 2012), and supplier satisfaction (Essig \& Amann, 2009; Ramsay \& Wagner, 2009), and preferred customer status (Schiele, Veldman, \& Hüttinger, 2011; Schiele, Veldman, Hüttinger, \& Pulles, 2012) are increasingly coming to the agenda in examining resource competition. This paper's social capital perspective on preferential resource allocation can provide a way forward to this upcoming stream of literature.

An interesting direction for future (empirical) research would be to examine how the dimensions of social capital connect to preferential resource allocation in the logic of time. If a potential partner has several collaborative opportunities with different firms, it will most likely engage in collaboration with the firm that is most attractive. However, the firm is not likely to directly allocate extensive resources to the relationship, as a preferred status must be established over time. The social capital dimensions may play different roles in building a preferred status. It can be argued that, before firms begin to collaborate and develop social capital, both partners must be sufficiently attractive for both firms to engage in the relationship. In this way, the different dimensions of social capital may be of differing importance depending of the stage of the relationship (Hüttinger, Schiele, \& Veldman, 2012; Mortensen, 2012). Furthermore, the structural and cognitive dimensions of social capital have been shown to relate to resource exchange both directly and by their positive effect on relational capital, in which the latter serves as a mediating variable (Tsai and Goshal, 1998). Future 
empirical research may incorporate this perspective and, in so doing, provide a better understanding of how the different dimensions of social capital relate to one another and to preferential resource allocation among firms.

Another direction for future research is suggested by an alternative explanation for preferential resource allocation between firms: It has been argued that symmetries in resource allocation are influence by a firm's relative bargaining power (Porter, 1980) and that firms with strong power positions can extract the best resources (e.g. Capron and Chatain, 2008). However, firms can obtain superior resource allocation despite the fact that other firms have a stronger bargaining positions. Dyer and Hatch (2006) provide an example of this and explain how Toyota entered the U.S. automobile industry while it had less relative bargaining power than its U.S. competitors due to smaller purchasing volumes. Still, despite this weak power position it was able to build close relationships with suppliers which enabled Toyota to increase its profit to an extent that is was larger "than the combined profits of GM, Ford, and DaimlerChrysler. Moreover, (...) Toyota's vehicles had roughly 40 percent fewer defects than those same competitors" (Dyer and Hatch, 2006, p. 702). Similarly, Christiansen and Maltz (2002), explain how small firms can attract large powerful suppliers and attain privileged access to leading edge technologies. Still, firms outside a cluster might aim to secure resource positions via their relative power (e.g., purchasing power). A discussion of social interaction versus power in regional clusters has shown to be a relevant discussion, and firms in regional clusters have an increased knowledge of social behaviors and an increased awareness of the use of power (Ireland \& Webb, 2007). Therefore, to fully examine the effect of the influence of power of firms outside the cluster, future research might focus on questions as; which perspective (power vs. social capital) is more important for resource allocation of firms within and outside regional clusters? What are the differences and what are the complementarities between these perspectives, and do they interact?

Finally, we use the concept of cluster embeddedness and state that the extent to which a firm is embedded in a regional cluster positively moderates the relationship between structural capital, relational capital, cognitive capital and the preferential resource allocation between firms. As we build on the social capital perspective, our framework might provide an explanation for why some cluster perform better than others and why proximity advantages alone is not sufficient to explain the competitive advantage of clusters (Kukalis, 2010; Steinle \& Schiele, 2008). As Westlund and Adam (2010) conclude from an extensive literature review; the social interaction on the level of individual firms has unambiguously shown to lead to higher levels of firm performance, on a regional level, however, the results were less clear. Incorporating the social capital dimensions and the cluster embeddedness perspective in future empirical research can help to explain why some clusters perform better than others. Literature provides examples on how to do this for the social capital dimensions. For example, structural embeddedness can be measured as the centrality (measured in number of inter-firm links) of a firm (Wasko \& Faraj, 2005). To measure cluster embeddedness, researchers could adopt reflective items as “our firm' s suppliers and competitors are located in proximity", or "my firm frequently interacts with firms from the same industry that are located nearby". In doing so, future empirical studies on the proposed 
moderating effect of cluster embeddedness on the social capital constructs from our framework might provide important insights into the differing levels of the competitive advantage of regional clusters.

\section{References}

Anderson, E., Lodish, L. M., \& Weitz, B. A. (1987). Resource allocation behavior in conventional channels. Journal of Marketing Research, 24(1), 85-97.

Andersson, U., Forsgren, M., \& Holm, U. (2002). The strategic impact of external networks: Subsidiary performance and competence development in the multinational corporation. Strategic Management Journal, 23(11), 979-996.

Aydalot, P. (1986). Milieux innovateurs en europe. Paris: GEMI.

Baptista, R., \& Swann, P. (1998). Do firms in clusters innovate more? Research Policy, 27(5), 525-540.

Barney, J. B. (1991). Firm resources and sustained competitive advantage. Journal of Management, 17(1), 99120.

Baxter, R. (2012). How can business buyers attract sellers' resources? Empirical evidence for preferred customer treatment from suppliers. Industrial Marketing Management, 41(8), 1249-1258.

Best, M. H. (1999). Regional growth dynamics: A capabilities perspective. Contributions to Political Economy, 18, 105-119.

Breschi, S., \& Lissoni, F. (2001). Knowledge spillovers and local innovation systems: A critical survey. Industrial and Corporate Change, 10(4), 975-1005.

Brown, K., Burgess, J., Festing, M., Royer, S., Steffen, C., \& Waterhouse, J. M. (2007). The value adding web - A conceptual framework of competitive advantage realisation in clusters. Paper presented at the Konferenzbeitrag auf der Tagung „Agglomeration and Growth in Knowledge-Based Societies "am Institut für Weltwirtschaft in Kiel.

Brown, K. A., Burgess, J., Festing, M., Royer, S., Steffen, C., Waterhouse, J. M., \& R. L. Keast, R. L. (2010). Conceptualising clusters as wverlapping value adding webs. In Brown, K., J. Burgess, M. Festing and S. Royer (Eds. ), Value adding webs and clusters: Concepts and cases, Rainer Hampp, München, Mering.

Capron, L., \& Chatain, O. (2008). Competitors' resource-oriented strategies: Acting on competitors' resources through interventions in factor markets and political markets. Academy of Management Review, 33(1), 97-121.

Christiansen, P. E., \& Maltz, A. (2002). Becoming an "interesting" customer: Procurement strategies for buyers without leverage. International Journal of Logistics Research and Applications, 5(2), 177-195.

Coleman, J. S. (1988). Social capital in the creation of human capital. The American Journal of Sociology, 94, 95-120.

Crevoisier, O. (2004). The innovative milieus approach: Toward a territorialized understanding of the economy? Economic Geography, 80(4), 367-379.

Dahl, M. S., \& Pedersen, C. Ø. R. (2004). Knowledge flows through informal contacts in industrial clusters: Myth or reality? Research Policy, 33(10), 1673-1686.

Das, T. K., \& Teng, B. -S. (2000). A resource-based theory of strategic alliances. Journal of Management, 26(1), 31-61.

Dijk, M. P. V., \& Sverrisson, Á. (2003). Enterprise clusters in developing countries: Mechanisms of transition and stagnation. Entrepreneurship \& Regional Development, 15(3), 183-206.

Doloreux, D., \& Parto, S. (2005). Regional innovation systems: Current discourse and unresolved issues. Technology in Society, 27(2), 133-153.

Duschek, S. (2004). Inter-firm resources and sustained competitive advantage. Management Rerme. The International Review of Management Studies, 15(1), 53-73.

Dyer, J. H., \& Hatch, N. W. (2006). Relation-specific capabilities and barriers to knowledge transfers: Creating advantage through network relationships. Strategic Management Journal, 27(8), 701-719.

Dyer, J. H., \& Singh, H. (1998). The relational view: Cooperative strategy and sources of interorganizational competitive advantage. Academy of Management Review, 23(4), 660-679. 
Ellegaard, C. (2012). Interpersonal Attraction in Buyer-Supplier Relationships: A Cyclical Model Rooted in Social Psychology. Industrial Marketing Management, 41(8), 1219-1227.

Ellis, S. C., Henke Jr., J. W., \& Kull, T. J. (2012). The effect of buyer behaviors on preferred customer status and access to supplier technological innovation: An empirical study of supplier perceptions. Industrial Marketing Management, 41(8), 1259-1269.

Enright, M. J. (1998). Regional clusters and firm strategy. In A. D. Chandler (Ed. ), The dynamic firm (pp. 315-342). Oxford etc. : Oxford Univ. Press.

Essig, M., \& Amann, M. (2009). Supplier satisfaction: Conceptual basics and explorative findings. Journal of Purchasing and Supply Management, 15(2), 103-113.

Fabiani, S., \& Pellegrini, G. (1998). Un' analisi quantitativa delle imprese nei distretti industriali italiani: Redditività, produttività e costo del lavoro [A quantitative analysis of the firms in industrial districts: Profitability, productivity and labour costs]. L'Industria. Rivista di Economia e Politica Industriale, 19(4), $5-25$.

Feldman, M. P. (1999). The new economics of innovation, spillovers and agglomeration: A review of empirical studies. Economics of Innovation and New Technology, 8(1-2), 5-25.

Festing, M., Royer, S., \& Steffen, C. (2010). Können Unternehmen durch Cluster Wettbewerbsvorteile realisieren? Eine ressourcenbasierte Analyse des Uhrenclusters Glashütte. Zeitschrift für Management, 5(2), 165-185.

Foss, N. J. (1999). Networks, capabilities, and competitive advantage. Scandinavian Journal of Management, 15(1), $1-15$.

Franz, P. (1999). Innovative milieus: Extrempunkte der Interpretation von Wirtschafts- und Wissenschaftssystemen. Jabrbuch fïr Regionalwissenschaft, 19(2), 107-130.

Freiling, J. (2004). A competence-base theory of the firm. Management Revue, 15(1), 27-52.

Fromhold-Eisebith, M. (1995). Das ' kreative milieu' als motor regionalwirtschaftlichr entwicklung. Forschungstrends und erfassungsmöglichkeiten. Geographische Zeitschrift, 83(1), 30-47.

Gulati, R. (1999). Network location and learning: The influence of network resources and firm capabilities on alliance formation. Strategic Management Journal, 20(5), 397-420.

Gulati, R., Lavie, D., \& Madhavan, R. (2011). How do networks matter? The performance effects of interorganizational networks. Research in Organizational Behavior, 31(0), 207-224.

Gulati, R., Nohria, N., \& Zaheer, A. (2000). Strategic networks. Strategic Management Journal, 21(3), 203215.

Gretzinger, S., \& Royer, S. (2011). Social and symbolic capital in firm clusters: An empirical investigation of relational resources and innovation capabilities. In Proceedings of the 5th European Conference on Innovation and Entrepreneurship, (pp. 417-425). Academic Conferences Limited.

Hald, K. S. (2012). The role of boundary spanners in the formation of customer attractiveness. Industrial Marketing Management, 41(8), 1228-1240.

Hallencreutz, D., \& Lundequist, P. E. R. (2003). Spatial clustering and the potential for policy practice: Experiences from cluster-building processes in sweden. European Planning Studies, 11(5), 533-547.

Heide, J. B., \& Miner, A. S. (1992). The shadow of the future: Effects of anticipated interaction and frequency of contact on buyer-seller cooperation. Academy of Management Journal, 35(2), 265-291.

Hult, G. T. M., Ketchen Jr., D. J., \& Slater, S. F. (2004). Information processing, knowledge development, and strategic supply chain performance. Academy of Management Journal, 47(2), 241-253.

Humphrey, J., \& Schmitz, H. (1998). Trust and inter-firm relations in developing and transition economies. Journal of Development Studies, 34(4), 32-61.

Hunt, S. D., \& Davis, D. F. (2008). Grounding supply chain management in resource-advantage theory. Journal of Supply Chain Management, 44(1), 10-21.

Hüttinger, L., Schiele, H., \& Veldman, J. (2012). The drivers of customer attractiveness, supplier satisfaction and preferred customer status: A literature review. Industrial Marketing Management, 41(8), 1194-1205.

Inkpen, A. C., \& Tsang, E. W. K. (2005). Social capital, networks, and knowledge transfer. Academy of Management Review, 30(1), 146-165. 
Ireland, R. D., Hitt, M. A., \& Vaidyanath, D. (2002). Alliance management as a source of competitive advantage. Journal of Management, 28(3), 413-446.

Ireland, R. D., \& Webb, J. W. (2007). A multi-theoretic perspective on trust and power in strategic supply chains. Journal of Operations Management, 25(2), 482-497.

Johnson Brown, J., \& Reingen, P. H. (1987). Social ties and word-of-mouth referral behavior. Journal of Consumer Research, 14(3), 350-362.

Kajikawa, Y., Takeda, Y., Sakata, I., \& Matsushima, K. (2010). Multiscale analysis of interfirm networks in regional clusters. Technovation, 30(3), 168-180.

Kankanhalli, A., Tan, B. C. Y., \& Wei, K. -K. (2005). Contributing knowledge to electronic knowledge repositories: An empirical investigation. MIS Quarterly, 29(1), 113-143.

Keeble, D., Lawson, C., Smith, H. L., Moore, B., \& Wilkinson, F. (1998). Internationalisation processes, networking and local embeddedness in technology-intensive small firms. Small Business Economics, 11(4), 327-342.

Krause, D. R., Handfield, R. B., \& Tyler, B. B. (2007). The relationships between supplier development, commitment, social capital accumulation and performance improvement. Journal of Operations Management, 25(2), 528-545.

Kukalis, S. (2010). Agglomeration economies and firm performance: The case of industry clusters. Journal of Management, 36(2), 453-481.

Lauterbach, C. E. (2005). Regionale Eertschöpfungssysteme und Kernkompetenzen: Konzept, empirische Untersuchung, Gestaltungsempfehlungen. München, Mering: Hampp.

Lavie, D. (2006). The competitive advantage of interconnected firms: An extension of the resource-based view. Academy of Management Review, 31(3), 638-658.

Lavie, D. (2007). Alliance portfolios and firm performance: A study of value creation and appropriation in the U. S. Software industry. Strategic Management Journal, 28(12), 1187-1212.

Leuthesser, L. (1997). Supplier relational behavior: An empirical assessment. Industrial Marketing Management, 26(3), 245-254.

Maillat, D. (1990). Innovation and local dynamism: The role of the milieu. Sociologia Internationalis, 28(2), 147-159.

Maskell, P. (2001). Towards a knowledg-based theory of the geographical cluster. Industrial and Corporate Change, 10(4), 921-943.

Maskell, P., \& Malmberg, A. (1999). Localised learning and industrial competitiveness. Cambridge Journal of Economics, 23, 167-185.

Mathews, J. A. (2002). A resource-based view of Schumpeterian economic dynamics. Journal of Evolutionary Economics, 12, 29-54.

McEvily, B., \& Zaheer, A. (1999). Bridging ties: A source of firm heterogeneity in competitive capabilities. Strategic Management Journal, 20(12), 1133-1156.

Mildenberger, U. (2001). Systemische Kompetenzen und deren Einfluss auf das Kompetenzentwicklungspotenzial in Produktionsnetzwerken. ZfbF Schmalenbachs Zeitschrift für betriebswirtschaftliche Forschung, 53, 705-722.

Mitchell, R., Burgess, J., \& Waterhouse, J. (2010). Proximity and knowledge sharing in clustered firms. International Journal of Globalisation and Small Business, 4(1), 5-24.

Molina-Morales, F. X., \& Martinez-Fernandez, M. T. (2003). The impact of industrial district affiliation on firm value creation. European Planning Studies, 11(2), 155-170.

Moran, P. (2005). Structural vs. relational embeddedness: Social capital and managerial performance. Strategic Management Journal, 26(12), 1129-1151.

Mortensen, M. H. (2012). Understanding attractiveness in business relationships - a complete literature review. Industrial Marketing Management, 41(8), 1206-1218.

Mortensen, M. H., Freytag, P. V., \& Arlbjørn, J. S. (2008). Attractiveness in supply chains: A process and matureness perspective. International Journal of Physical Distribution and Logistics Management, 38(10), 799-815. 
Nahapiet, J., \& Ghoshal, S. (1998). Social capital, intellectual capital, and the organizational advantage. Academy of Management Review, 23(2), 242-266.

Newbert, S. L. (2008). Value, rareness, competitive advantage, and performance: A conceptual-level empirical investigation of the resource-based view of the firm. Strategic Management Journal, 29(7), 745-768.

Nollet, J. Rebolleda, C. \& Popel, V. (2012). Becoming a preferred customer one step at a time. Industrial Marketing Management, 41(8), 1186-1193.

Oba, B., \& Semerciöz, F. (2005). Antecedents of trust in industrial districts: An empirical analysis of interfirm relations in a turkish industrial district. Entrepreneurship \& Regional Development, 17(3), 163-182.

Palmatier, R. W., Gopalakrishna, S., \& Houston, M. B. (2006). Returns on business-to-business relationship marketing investments: Strategies for leveraging profits. Marketing Science, 25(5), 477493.

Peteraf, M. A. (1993). The cornerstones of competitive advantage: A resource-based view. Strategic Management Journal, 14(3), 179-191.

Porter, M. E. (1980). Competitive strategy: Techniques for analyzing industries and competitors. New York, NY etc. : Free Press.

Porter, M. E. (1990). The competitive advantage of nations. London: Macmillan.

Porter, M. E. (1998). Clusters and competition: New agendas for companies, governments, and institutions. Boston (MA): Harvard Business School Press.

Portes, A. (1998). Social capital: Its origins and applications in modern sociology. Annual Review of Sociology, 24, 1-24.

Ramsay, J., \& Wagner, B. A. (2009). Organisational supplying behaviour: Understanding supplier needs, wants and preferences. Journal of Purchasing and Supply Management, 15(2), 127-138.

Ridings, C. M., Gefen, D., \& Arinze, B. (2002). Some antecedents and effects of trust in virtual communities. The Journal of Strategic Information Systems, 11(3-4), 271-295.

Romanelli, E., \& Khessina, O. M. (2005). Regional industrial identity: Cluster configurations and economic development. Organization Science, 16(4), 344-358.

Rowley, T., Behrens, D., \& Krackhardt, D. (2000). Redundant governance structures: An analysis of structural and relational embeddedness in the steel and semiconductor industries. Strategic Management Journal, 21(3), 369-386.

Rutten, R., Westlund, H., \& Boekema, F. (2010). The spatial dimension of social capital. European Planning Studies, 18(6), 863-871.

Sanchez, R., \& Heene, A. (1997). Reinventing strategic management: New theory and practice for competence-based competition. European Management Journal, 15(3), 303-317.

Schiele, H., Veldman, J., \& Hüttinger, L. (2011). Supplier innovativeness and supplier pricing: The role of preferred customer status. International Journal of Innovation Management, 15(1), 1-27.

Schiele, H., Veldman, J., Hüttinger, L., \& Pulles, N. (2012). Towards a social exchange theory perspective on preferred customership - concept and practice. In R. Bogaschewsky, M. Eßig, R. Lasch \& W. Stölzle (Eds. ), Supply management research (pp. 133-151): Gabler Verlag.

Staber, U. D. O. (2007). Contextualizing research on social capital in regional clusters. International Journal of Urban and Regional Research, 31(3), 505-521.

Steinle, C., Eickhoff, M., \& Schiele, H. (1998). Zur Perspektivenerweiterung des strategischen Management: Der 'Innovative Cluster' als Wertschöpfungssystem und die Entwicklung von Kernkompetenzen. Zeitscbrift für Planung, 9(4), 367-390.

Steinle, C., \& Schiele, H. (2002). When do industries cluster?: A proposal on how to assess an industry's propensity to concentrate at a single region or nation. Research Policy, 31(0), 849-858.

Steinle, C., \& Schiele, H. (2008). Limits to global sourcing?: Strategic consequences of dependency on international suppliers: Cluster theory, resource-based view and case studies. Journal of Purchasing and Supply Management, 14(1), 3-14. 
Steinle, C., Schiele, H., \& Mietzner, K. (2007). Merging a firm-centred and a regional policy perspective for the assessment of regional clusters: Concept and application of a "dual" approach to a medical technology cluster. European Planning Studies, 15(2), 235-251.

Takeishi, A. (2001). Bridging inter- and intra-firm boundaries: Management of supplier involvement in automobile product development. Strategic Management Journal, 22(5), 403-433.

Takeishi, A. (2002). Knowledge partitioning in the interfirm division of labor: The case of automotive product development. Organization Science, 13(3), 321-338.

Tallman, S., Jenkins, M., Henry, N., \& Pinch, S. (2004). Knowledge, clusters, and competitive advantage. Academy of Management Review, 29(2), 258-271.

Tsai, W., \& Ghoshal, S. (1998). Social capital and value creation: The role of intrafirm networks. Academy of Management Journal, 41(4), 464-476.

Wasko, M. M., \& Faraj, S. (2005). Why should I share? Examining social capital and knowledge contribution in electronic networks of practice. MIS Quarterly, 29(1), 35-57.

Westlund, H., \& Adam, F. (2010). Social capital and economic performance: A meta-analysis of 65 studies. European Planning Studies, 18(0), 893-919.

Wood, A. M., Watts, H. D., \& Wardle, P. (2004). Growth-oriented small firms and the nature and extent of local embeddedness: The case of a traditional metalworking cluster. Growth and Change, 35(4), 419-433.

Zaheer, A., \& George, V. P. (2004). Reach out or reach within? Performance implications of alliances and location in biotechnology. Managerial and Decision Economics, 25(6-7), 437-452. 